\title{
Современное состояние химиотерапии и профилактики гриппа и ОРВИ в Украине
}

В настоящее время существует несколько разрешенных к применению препаратов для лечения гриппа, однако их эффективность ограничивается появлением лекарственно устойчивых форм вирусов и наличием противопоказаний. Кроме того, в период эпидемии гриппа диагностируют и другие респираторные вирусные инфекции, схожие по симптоматике, в отношении которых противогриппозные препараты неэффективны. Помимо синтетических ингибиторов нейраминидазы вируса гриппа существует целый ряд природных веществ, относящихся к флавоноидам, которые обладают ингибирующей активностью в отношении нейраминидазы. Рассмотрены перспективы использования флавоноидов как противовирусных средств. Важной особенностью флавоноидов как биологически активных молекул является полимишеневый механизм их действия. Приведены данные литературы и собственных исследований противовирусной активности отечественных флавоноидсодержащих препаратов Протефлазид ${ }^{\circledR}$ и Иммунофлазид ${ }^{\circledR}$, которые могут быть рекомендованы в качестве этиотропного и патогенетического средства для профилактики и лечения гриппа и острых респираторных вирусных инфекций.

ключевые слова: грипп, ингибиторы нейраминидазы, флавоноиды, Протефлазид ${ }^{\circledR}$, Иммунофлазид $^{\circledR}$.

Несмотря на наличие вакцинопрофилактики и определенной противовирусной терапии, вирусы гриппа и острых респираторных вирусных инфекций (ОРВИ) продолжают оказывать ежегодное существенное влияние на заболеваемость и смертность людей, что подтверждает сохраняющуюся потребность в поиске эффективных лекарственных средств для лечения и профилактики гриппа и ОРВИ.

Значительным достижением современной биологии и медицины является разработка и внедрение в практику этиотропных методов терапии вирусных инфекций, основанных на применении специфических ингибиторов, блокирующих функциональную активность вируса на разных этапах его цикла репликации. Первыми разработанными противовирусными препаратами были ингибиторы ДНК- и РНК-полимераз. Впоследствии внимание исследователей было обращено и на другие специфические ферменты вирусов, в частности на нейраминидазу вируса гриппа. На смену противогриппозным препаратам I поколения, являющихся блокаторами $\mathrm{M}_{2}$-каналов вирусных частиц (амантадин, римантадин), пришли препараты II поколения - ингибиторь нейраминидазы, которые оказались более специфическими и менее токсичными, к тому же, в отличие от ингибиторов I поколения, к ним значительно слабее вырабатывалась резистентнОсть

Нейраминидаза является ферментом вирионов, благодаря действию которого происходит высвобождение вируса гриппа из клеток. Именно этот фермент способствует распространению вируса по респираторному тракту с инфицированием большого количества клеток. Хотя генетическая структура вирусов гриппа и их нейраминидаза постоянно меняются, аминокислотная последовательность активного участка фермента остается постоянной. Это и делает нейраминидазу идеальной мишенью для противовирусной терапии. Первые ингибиторы нейраминидазы синтезированы еще в 1960-е годы (Edmond J.D. et al., 1966), однако апробированные препараты, вошедшие в практику здравоохранения, появились значительно позднее, когда в 1980-егоды была установлена трехмерная структура очищенной нейраминидазы, что послужило основой для разработки синтетических ингибиторов этого фермента на основе целенаправленного молекулярного дизайна препаратов с селективным действием.

В настоящее время в США доступны пять лицензированных рецептурных препаратов против вируса гриппа, являющихся синтетическими ингибиторами нейраминидазы. Три из них одобрены Управлением по контролю за пищевыми продуктами и лекарственными средствами США(US Food and Drug Administration FDA) как противогриппозные препараты: осельтамивир - для перорального, занамивир - для ингаляционного и перамивир - для внутривенного применения. Эффективность и специфичность этих препаратов доказана в клинических испытаниях. Препараты рекомендованы как для применения в терапевтических целях, так и для профилактики гриппа в условиях начинающейся эпидемии.

Вместе с тем существует ряд проблем, связанных с применением синтетических ингибиторов нейраминидазы. Во-первых, несмотря на их более низкую токсичность в сравнении с препаратами I поколения, ингибиторы нейраминидазы не лишены ряда побочных эффектов. Поэтому применять их с профилактической целью рекомендовано только в группах повышенного риска. Кроме того, применение ингибиторов нейраминидазы не снимает вопроса развития резистентности к этим препаратам, что связано с высокой изменчивостью вирусов гриппа. Следует отметить, что развитие резистентности к препаратам I поколения стало важным фактором ограничения их применения. В отношении ингибиторов нейраминидазы развитие резистентности пока не носит глобального характера, чему в немалой степени способствует высококонсервативная структура активного центра этого фермента. Так, в первые годы применения этих препаратов чувствительность к ним клинических изолятов вирусов гриппа в мире практически не менялась. Однако уже в эпидемию 20072008 гг. выявлено спонтанное возникновение и распространение вирусов H1N1, резистентных к осельтамивиру (Meijer A. et al., 2009), хотя суммарная частота таких резистентных штаммов не превышала 2\%, и, согласно последним данным, на 2016 г. у большинства изолятов вирусов гриппа выявлена чувствительность при тестировании четырех известных препаратов ингибиторов нейраминидазы (Gubareva L.V. et al., 2017). Вместе с тем в литературе подчеркивается настоятельная необходимость постоянного мониторинга новых изолятов вирусов гриппа с тем, чтобы внезапное появление и распространение резистентных к ингибиторам нейраминидазы вирусов не было неожиданным для служб здравоохранения. Кроме того, постоянно продолжается поиск новых действующих веществ, которые бы эффективно ингибировали нейраминидазу вируса гриппа и другие критические этапы его репродукции.

Помимо поиска и конструирования синтетических соединений, эффективно ингибирующих нейраминидазу вируса гриппа, активно развивается и другое направление, связанное с ингибированием нейраминидазы веществами природного происхождения, особое место среди которых занимают растительные полифенолы, в частности - флавоноиды. Эти соединения, широко распространенные в растительном мире, проявляют множествен- 
ные эффекты в клетках, взаимодействуя с различными биологическими молекулами и оказывая модулирующее действие на целый ряд внутриклеточных процессов.

В конце XX ст. продемонстрированы противовирусные свойства ряда веществ этого класса и показана зависимость противовирусной активности в разных системах от молекулярной структуры этих соединений. Не стали исключением и вирусы гриппа. В экспериментах in vitro и in vivo продемонстрирована ингибирующая активность ряда флавоноидов в отношении гриппозной инфекции. Долгое время о специфической противовирусной активности флавоноидов речь не шла и противовирусные эффекты, порой весьма существенные, объясняли, лишь исходя из мощной антиоксидантной активности этих соединений. Между тем, еще до широкого распространения исследований по типу «структура - активность» с использованием метода докинга продемонстрирован ингибирующий эффект ряда флавоноидов в отношении нейраминидазы вируса гриппа. Так, при исследовании большого количества флавоноидов практически у всех их выявлена ингибирующая активность в отношении нейраминидазы с $\mathrm{IC}_{50}$ в диапазоне 0,8-56,9 мкмоль/л (Jeong H.J. et al., 2009). Скрининг флавоноидов относительно ингибирования активности нейраминидазы показал большой потенциал этих веществ для создания возможных препаратов против гриппозной инфекции (Nagai T. et al., 1990). Изучение кинетики ингибирования нейраминидазы продемонстрировало неконкурентный (На T.K. et al., 2016), а в отношении ряда флавоноидов - и конкурентный механизм ингибирования (Nguyen T.T.H. et al., 2014). Связывание ряда флавоноидов с активным центром нейраминидазы вируса гриппа, что важно для конкурентного ингибирования этого фермента, продемонстрировано и при использовании метода докинга (Mercader A.G., Pomilio A.B., 2010; Nguyen T.T.H. et al., 2014). Этим же методом выявлен ряд перспективных ингибиторов нейраминидазы среди синтезированных производных флавоноидов (Lu S.J., Chong F.C., 2012).

Важной особенностью флавоноидов (как биологически активных молекул) является полимишеневый механизм их действия, детально проанализированный в ряде работ последних лет. Отметим, что системный анализ действия фармакологических средств свидетельствует о том, что в определенных ситуациях суммарный клинический эффект полимишеневых субстанций с учетом всех факторов, включая токсические эффекты, может быть лучше, чем у субстанций с высокой селективностью (Норkins A.L., 2008).

Множественный противовирусный эффект флавоноидов ингибирование вирусоспецифических ферментов ДНК- и РНКполимераз, тимидинкиназы, обратной транскриптазы и нейраминидазы - отличает их от специфических высокоселективных ингибиторов нейраминидазы (осельтамивир, занамивир, перамивир), действие которых исчерпывается лишь ингибированием одного фермента нейраминидазы (хотя и высокоспецифическим). Сравнительные данные ингибирующего эффекта в отношении нейраминидазы свидетельствуют о довольно значительной разнице величин $\mathrm{IC}_{50}$ У флавоноидов и высокоспецифических ингибиторов ( $\mathrm{IC}_{50}$ У последних находится в наномолярном диапазоне) (Grienke U. et al., 2012). Вместе с тем, именно полифармакологический характер действия флавоноидов позволяет обозначить перспективы их использования как противовирусных средств не только в отношении гриппозной инфекции. Целенаправленный поиск природных веществ флавоноидной природы на основе подходов с использованием метода докинга позволил выявить флавоноиды со значительно более низкими величинами $\mathrm{IC}_{50}$ в отношении ингибирования нейраминидазыпорядка 1 мкмоль/л (Lee C.H. et al., 2003; Grienke U. et al., 2010) и определить перспективные для дальнейшего поиска и изучения структуры. Показана корреляция между прогнозированной докингом эффективностью ингибирования нейраминидазы и подавлением цитопатогенного действия вируса гриппа в культуре ткани (Liu A.L. et al., 2008).

Помимо того что флавоноиды и полифенолы в целом характеризуются полимишеневым действием, в экспериментальных исследованиях показан синергизм некоторых полифенолов с осельтамивиром в отношении ингибирования репродукции вируса гриппа (Haidari M. et al., 2009), что может найти практиче- ское применение в комплексной терапии гриппа в сочетании со специфическими ингибиторами нейраминидазы. Также отметим, что ингибирующий эффект некоторых флавоноидов продемонстрирован и в отношении штаммов, резистентных к осельтамивиру (На T.K. et al., 2016) и перамивиру (Kai H. et al., 2014).

При изучении проблем, связанных с разработкой новых лекарственных средств против гриппозной инфекции, высказывается мнение о том, что препараты следующих поколений, помимо ингибирования нейраминидазы, должны воздействовать и на другие критические мишени (Hayden F., 2009). Этот подход уже используется в научных исследованиях противовирусного действия флавоноидов. Так, продемонстрировано, что кверцетин не только обладает ингибирующим действием в отношении нейраминидазы, но и связывается с гемагглютинином вируса и препятствует прикреплению вируса к клетке и проникновению в нее, а также препятствует гемолизу, опосредуемому гемагглютинином (Wu W. et al., 2015). При изучении противовирусного действия ороксилина показано сочетание ингибирования нейраминидазы с индукцией интерферона, что также важно в опосредовании противовирусных эффектов (Jin J. et al., 2017).

Не остались в стороне от этого важного направления в исследовании и разработке противовирусных препаратов и исследователи в Украине. Благодаря сотрудничеству исследователейвирусологов ГУ «Институт эпидемиологии и инфекционных болезней имени Л.В. Громашевского НАМН Украины” и научного департамента «Научно-производственной компании «Экофарм» в Украине создан, испытан и успешно апробирован флавоноидсодержащий лекарственный препарат Протефлазид ${ }^{\circledR}$, представляющий собой спиртовый экстракт из двух диких злаков, произрастающих в Украине - Deschampsia caespitosa L. (щучка дернистая) и Calamagrostis epigeios L. (вейник наземный). Полученный препарат характеризуется оригинальным составом, представленным агликонами флавоноидов (трицин, апигенин, лютеолин) и их О- и С-гликозидами, находящимися в матрице вспомогательных веществ - аминокислот, карбоновых кислот и сахаров. Технология получения препарата обеспечивает охарактеризованный химический состав и стабильное соотношение различных его компонентов (Атаманюк В.П., Новик А.М., 2015). Разработана и апробирована лекарственная форма препарата Протефлазид ${ }^{\circledR}$ в форме суппозиториев, а также препарата для детей в форме сиропа - Иммунофлазид ${ }^{\oplus}$.

СпециалистамиГУ «Институт эпидемиологии и инфекционных болезней имени Л.В. Громашевского НАМН Украины» проведены исследования противогриппозной активности и механизмов действия препарата Протефлазид ${ }^{\circledR}$ в экспериментах in vitro и in vivo. На модели гриппозной инфекции перевиваемых клеток MDCK показано, что Протефлазид ${ }^{\circledR}$ эффективно ингибирует репродукцию вируса гриппа. Снижение титра вируса не менее чем на 2 IgID ${ }_{50}$ отмечено уже в дозе 0,045 мкг/мл как при профилактическом (обработка препаратом до заражения вирусом), так и терапевтическом режиме применения при высоком значении химиотерапевтического индекса благодаря низкой токсичности препарата.

Ранее в проведенных нами исследованиях in vitro на различных моделях вирусных инфекций показано, что ингибирование вирусоспецифических ферментов, таких как ДНК- и РНКполимеразы, тимидинкиназа, обратная транскриптаза и нейраминидаза, является одним из важных механизмов противовирусного действия препарата Протефлазид ${ }^{\circledR}$ в отношении вирусов различных групп (Пальчиковська Л.Г. та співавт., 2013). Нами продемонстрировано непосредственное ингибирующее действие препарата и на активность нейраминидазы вируса гриппа. Так, при концентрации препарата в инкубационной смеси для определения нейраминидазной активности в 4,5 мкг/мл отмечено полное ингибирование активности фермента нейраминидазы различных штаммов вируса гриппа А. Эти данные свидетельствуют о том, что нейраминидаза является одной из молекулярных мишеней действия указанного флавоноидсодержащего препарата. Показано, что препарат на основе агликонов флавонов проявляет синергизм в отношении вируса гриппа, действуя на различные критические звенья его репродукции (ингибиция PHК-полимеразы), в том числе блокирует (ингибиция нейраминидазы) прикрепление и выход вируса из клеток-мишеней. 
В экспериментах in vivo на модели гриппозной инфекции мышей при интраназальном заражении вирусом показано, что Протефлазид ${ }^{\circledR}$ при внутрибрюшинном введении оказывал противовирусный эффект как при профилактическом введении за 244 до заражения вирусом, так и при терапевтическом введении спустя 24 ч после заражения. Эффективные дозы, защищающие мышей от летальной гриппозной инфекции, составили 4,8 мкг/кг при профилактическом и 0,96 мкг/кг - при терапевтическом введении; для сравнения дозы осельтамивира составляли 1000 и 1000 мкг/кг соответственно, при этом индекс эффективности был сопоставим с показателем осельтамивира, используемого в качестве позитивного контроля.

В доклинических исследованиях Протефлазид ${ }^{\circledR}$ показал высокую специфическую противовирусную активность (на $>2 \lg I D_{50}$ ) и на моделях аденовируса и ряда других вирусов с респираторным компонентом в патогенезе вызываемых ими заболеваний (таблица)

Таблица. Показатели противовирусной активности препарата Протефлазид ${ }^{\circledR}$ in vitro на различных моделях

\begin{tabular}{lccc}
\hline \multicolumn{1}{c}{ Вирус } & $\mathbf{C C}_{50}, \mathbf{M K г} / \mathbf{M л}$ & $\mathbf{E C}_{50}, \mathbf{M K г} / \mathbf{M л}$ & ХТИ \\
\hline Грипп H1N1 & 7 & 0,045 & 155,6 \\
Аденовирус & 6,4 & 0,2 & 32 \\
Вирус герпеса простого-1 & 6,8 & 0,052 & 130 \\
Вирус Эпштейна - Барр & 40 & 0,1 & 400 \\
\hline
\end{tabular}

$\mathrm{CC}_{50}$ - цитотоксическая концентрация препарата в культуре ткани, вызывающая гибель $50 \%$ клеток; $\mathrm{EC}_{50}$ - действующая концентрация препарата, вызывающая торможение репликации исследуемого вируса на 50\%; ХТИ - химиотерапевтический индекс.

Приведенные данные являются основанием для рекомендаций по применению препарата Протефлазид ${ }^{\circledR}$ в период повышенной сезонной заболеваемости ОРВИ еще и по той причине, что, наряду с вирусами гриппа, источниками таких заболеваний могут быть и другие вирусы (аденовирус, энтеровирус, респираторно-синцитиальный и др.), для лечения которых специфические ингибиторы нейраминидазы неэффективны.

Доклинические и клинические исследования препаратов Протефлазид ${ }^{\circledR}$ и Иммунофлазид ${ }^{\circledR}$ показали, помимо прямого противовирусного действия, иммунотропный и антиоксидантный эффекты (Крамарев С.А. и соавт., 2014). В частности механизм иммунотропного действия состоит в индукции синтеза эндогенных $\alpha$ - и ү-интерферонов. Флавоноиды усиливают действие апоптоз-индуцирующихвеществ, что способствует более быстрой элиминации пораженных вирусом клеток и профилактике развития хронических заболеваний на фоне латентных вирусных инфекций. Данные клинических исследований свидетельствуют, что, помимо этиотропного воздействия на вирусную инфекцию (которое само по себе осуществляется полимишеневым противовирусным механизмом действия), препараты Протефлазид и Иммунофлазид ${ }^{\circledR}$ позволяют устранять негативные последствия воздействия вирусной инфекции на организм человека (устранение воспаления слизистой оболочки носа, горла и легких, восстановление температурного режима, устранение интоксикации и т.д.) (Бекетова Г.В. и соавт., 2014; Абатуров А.Е., Высочина И.Л. 2016). Кроме того, улучшение клинического состояния пациентов, принимающих препараты Протефлазид ${ }^{\circledR}$ и Иммунофлазид ${ }^{\circledR}$, происходит на фоне нормализации показателей клеточного иммунитета, что также служит дополнительным обоснованием для включения этих лекарственных средств в комплекс лечения и профилактики гриппа и ОРВИ (Кузнецова Л.В., 2017).

Флавоноидсодержащие препараты Протефлазид ${ }^{\circledR}$, Иммунофлазид ${ }^{\circledR}$ и Протефлазид ${ }^{\circledR}$ в форме суппозиториев прошли $>130$ клинических испытаний в различных клиниках Украинь и показали эффективность в лечении и профилактике гриппа и ОРВИ, а также ряда других вирусных инфекций. Данные анализа результатов клинических исследований суммированы в ряде работ (Бекетова Г.В. и соавт., 2014; Крамарев С.А. и соавт., 2014). Клинические результаты подтверждают данные экспериментальных исследований о наличии полифармакологических свойств у препаратов Протефлазид ${ }^{\circledR}$ и Иммунофлазид ${ }^{\circledR}$ на уровне как мишеней, связанных с репликацией вируса, так и защитных систем организма в целом, что характерно для фармакодинамики флавоноидов как основных компонентов препаратов. Проанализированные результаты клинических исследований подтверждают клиническую эффективность и вы- сокий профиль безопасности препаратов не только у взрослых, но и у детей при применении как с лечебной, так и с профилактической целью (Токарчук Н.І., Старинець Л.С., 2012; Муквіч О.М., Камінська Т.М., 2017). Важно также отметить, что применение агликонов флавонов может быть показано в период повышенной сезонной заболеваемости гриппом и ОРВИ и по той причине, что, наряду с вирусами гриппа, источниками респираторных заболеваний могут быть и другие вирусы, для лечения которых специфические ингибиторы нейраминидазы неэффективны, в то время как специфическая серологическая диагностика в массовом масштабе не проводится.

Таким образом, результаты доклинических исследований, доказательная база клинической эффективности и безопасности, а также опубликованные научные и литературные данные позволяют сделать вывод о том, что препараты Протефлазид ${ }^{\circledR}$ и Иммунофлазид ${ }^{\circledR}$ могут быть рекомендованы для контроля современных сезонных эпидемий гриппа и ОРВИ в качестве этиотропных и патогенетических препаратов как в схемах лечения, так и для профилактики у пациентов всех возрастных групп.

\section{Список использованной литературы}

Абатуров А.Е., Высочина И.Л. (2016) Реализация противовирусного и антиоксидантного действия биофлавоноидов при лечении острых респираторных вирусных инфекций. Здоровье ребенка, 5(73): 42-48.

Атаманюк В.П., Новик А.М. (2015) Винахід «Біологічно-активна речовина поліфармакологічної дії рослинного походження» (№ а 2015 03915).

Бекетова Г.В., Хайтович Н.В., Гриневич А.И. (2014) Иммунофлазид в педиатрии: системный анализ эффективности и безопасности применения. Педиатрия. Восточная Европа, 3(7): 141-152.

Крамарев С.А., Гриневич А.И., Тонковид О.Б., Выговская О.В. (2014) Метаанализ результатов клинических исследований эффективности флавоноидов при вирусных и вирусно-бактериальных заболеваниях у детей. Совр. педиатр., 5(61): 1-7

Кузнецова Л.В. (2017) Влияние флавоноидов на показатели клеточного иммунитета у детей и подростков, которые болеют гриппом и острыми респираторными вирусными инфекциями, до и после лечения. Лабораторная диагностика. Восточная Европа, 6(3): 429-436.

Муквіч О.М., Камінська Т.М. (2017) Превентивна та лікувальна ефективність біофлавоноїдів у дітей з рекурентними респіраторними інфекціями. Здоров'я дитини, 12(2): 124-129.

Пальчиковська Л.Г., Васильченко О.В., Платонов М.О. та ін. (2013) Антивірусні властивості рослинних флавоноїдів - інгібіторів синтезу ДНК і РНК. Biopolymers Cell, 29(2): 150-156.

Токарчук Н.І., Старинець Л.С. (2012) Використання Імунофлазіду для профілактики та лікування грипу і ГРВІ у дітей під час сезонного підвищення захворюваності. Совр. педиатр., 1(41): 123-127.

Edmond J.D., Johnston R.G., Kidd D. et al. (1966) The inhibition of neuraminidase and antiviral action. Br. J. Pharmacol. Chemother., 27(2): 415-426.

Grienke U., Schmidtke M., Kirchmair J. et al. (2010) Antiviral potential and molecular insight into neuraminidase inhibiting diarylheptanoids from Alpinia katsumadai. J. Med. Chem., 53(2): 778-786.

Grienke U., Schmidtke M., von Grafenstein S. et al. (2012) Influenza neuraminidase: a druggable target for natural products. Nat. Prod. Rep., 29(1): $11-36$

Gubareva L.V., Besselaar T.G., Daniels R.S. et al. (2017) Global update on the susceptibility of human influenza viruses to neuraminidase inhibitors, 2015-2016. Antiviral Res., 146: 12-20.

Ha T.K., Dao T.T., Nguyen N.H. et al. (2016) Antiviral phenolics from the leaves of Cleistocalyx operculatus. Fitoterapia, 110: 135-141.

Haidari M., Ali M., Ward Casscells S. 3rd, Madjid M. (2009) Pomegranate (Punica granatum) purified polyphenol extract inhibits influenza virus and has a synergistic effect with oseltamivir. Phytomedicine, 16(12): 1127-1136.

Hayden F. (2009) Developing new antiviral agents for influenza treatment: what does the future hold? Clin. Infect. Dis., 48(1): S3-S13.

Hopkins A.L. (2008) Network pharmacology: the next paradigm in drug discovery. Nat. Chem. Biol., 4(11): 682-690.

Jeong H.J., Ryu Y.B., Park S.J. et al. (2009) Neuraminidase inhibitory activities of flavonols isolated from Rhodiola rosea roots and their in vitro anti-influenza viral activities. Bioorg. Med. Chem., 17(19): 6816-6823.

Jin J., Chen S., Wang D. et al. (2017) Oroxylin A suppresses influenza A virus replication correlating with neuraminidase inhibition and induction of IFNs. Biomed. Pharmacother., 97: 385-394.

Kai H., Obuchi M., Yoshida H. et al. (2014) In vitro and in vivo anti-influenza virus activities of flavonoids and related compounds as components of Brazilian propolis (AF-08). J. Funct. Foods, 8: 214-223.

Lee C.H., Kim S.I., Lee K.B. et al. (2003) Neuraminidase inhibitors from Reynoutria elliptica. Arch. Pharm. Res., 26(5): 367-374. 
Liu A.L., Wang H.D., Lee S.M. et al. (2008) Structure-activity relationship of flavonoids as influenza virus neuraminidase inhibitors and their in vitro anti-viral activities. Bioorg. Med. Chem., 16(15): 7141-7147.

Lu S.J., Chong F.C. (2012) Combining molecular docking and molecular dynamics to predict the binding modes of flavonoid derivatives with the neuraminidase of the 2009 H1N1 influenza A virus. Int. J. Mol. Sci., 13(4): 4496-4507.

Meijer A., Lackenby A., Hungnes 0. et al.; European Influenza Surveillance Scheme (2009) Oseltamivir-resistant influenza virus A (H1N1), Europe, 2007-08 season. Emerg. Infect. Dis., 15(4): 552-560.

Mercader A.G., Pomilio A.B. (2010) QSAR study of flavonoids and biflavonoids as influenza H1N1 virus neuraminidase inhibitors. Eur. J. Med. Chem., 45(5): 1724-1730.

Nagai T., Miyaichi Y., Tomimori T. et al. (1990) Inhibition of influenza virus sialidase and anti-influenza virus activity by plant flavonoids. Chem. Pharm. Bull. (Tokyo), 38(5): 1329-1332.

Nguyen T.T.H., Kang H.K., Kim Y.M. et al. (2014) Inhibition effect of flavonoid compounds against neuraminidase expressed in Pichia pastoris. Biotechnol. Bioproc. Engineer., 19: 70-75.

Wu W., Li R., Li X. et al. (2015) Quercetin as an antiviral agent inhibits influenza A virus (IAV) entry. Viruses, 8: E6.

\section{Сучасний стан хіміотерапії і профілактики грипу та ГРВІ в Україні С.Л. Рибалко, Д.Б. Старосила, М.П. Завелевич}

Резюме. Сьогодні існує декілька дозволених до застосування препаратів для лікування грипу, проте їх ефективність обмежується появою стійких до ліків форм вірусів і наявністю протипоказань. Крім того, в період епідемії грипу діагностують й інші респіраторні вірусн інфекції, схожі за симптоматикою, щодо яких протигрипозні препарати неефективні. Окрім синтетичних інгібіторів нейрамінідази вірусугрипу, існує ціла низка природних речовин, що належать до флавоноїдів, яким також властива інгібуюча активність щодо нейрамінідази. Розглянуто перспективи застосування флавоноїдів як противірусних засобів. Важливою особливістю флавоноїдів як біологічно активних молекул є полімішеневий механізм дії. Наведено дані літератури та власних досліджень противірусної активності вітчизняних флавоноїдвмісних препаратів Протефлазід ${ }^{\circledast}$ та Імунофлазід ${ }^{\oplus}$, які можуть бути рекомендовані як етіотропний та патогенетичний засіб для профілактики і лікування грипу та гострих респіраторних вірусних інфекцій.

Ключові слова: грип, інгібітори нейрамінідази, флавоноїди, Протефлазід ${ }^{\circledR}$ Імунофлазід

\section{Current state of chemotherapy and prevention of influenza and ARVI in Ukraine}

\section{S.L. Rybalko, D.B. Starosyla, M.P. Zavelevich}

Summary. At present, several approved medicinal drugs for the treatment of influenza are available. Nevertheless, their efficacy is limited by the emergence of drug-resistant forms of viruses and some contraindications. Moreover, other respiratory viral infections are diagnosed in the setting of flu epidemics. While such infections are similar to influenza by their symptom, antiflu agents fail to control them. Besides synthetic neuraminidase inhibitors, a wide range of the natural substances belonging to flavonoids, also possess the activity as neuraminidase inhibition. The prospects for the application of flavonoids as antiviral agents are reviewed. The multi-target mechanism of flavonoid effects is of high importance. The literature data and the results of our own studies of the domestic flavonoid-containing drugs Proteflazid ${ }^{\circledR}$ and Immunoflazid ${ }^{\circledR}$ suggest that they may be recommended as etiotropic and pathogenetic remedy for preventing and treating influenza and other acute respiratory viral infection.

Key words: influenza, neuraminidase inhibitors, flavonoids, Proteflazid ${ }^{\circledast}$, Immunoflazid ${ }^{\circledR}$.

\section{Адрес для переписки:}

Рыбалко Светлана Леонтьевна

03680, Киев, ул. Н. Амосова, 5

Институт эпидемиологии и инфекционных болезней

им. Л.В. Громашевского НАМН Украины,

лаборатория моделирования экспериментальной химиотерапии

вирусных инфекций

E-mail epidemics@ukr.net

Получено 09.02.2018

Информация для профессиональной деятельности медицинских и фармацевтических работников

ПРОТЕФЛАЗИД ${ }^{\circ}$. Состав. 1 мл капель содержит 1 мл жидкого экстракта Протефлазид из трав щучки дернистой и вейника наземного 1:1. ИммУноФлАЗидФ. Состав. 1 мл сиропа содержит 0,02 мл жидкого экстракта Протефлазид из трав щучки дернистой и вейника наземного 1:1. Код АТС. J05А Х20**. Фармакотерапевтическая группа. Противовирусные средства прямого действия. Фармакологические свойства. Флавоноиды, входящие в состав препаратов, подавляют репликацию ДНК- и РНК-вирусов in vitro и in vivo. Оказывают противовирусное действие в отношении вирусов герпеса, гепатита, папилломавирусов, ВИЧ-инфекции, гриппа и острых респираторных инфекций. Механизм прямого противовирусного действия заключается в ингибировании вирусоспецифических ферментов - ДНК- и РНК-полимераз, тимидинкиназы, обратной транскриптазы и нейраминидазы. Обладают иммунотропными, антиоксидантными свойствами. Побочные эффекты. Аллергические реакции, желудочно-кишечные расстройства, общие расстройства и др.

Полная информация о лекарственных средствах содержится в инструкциях по медицинскому применению. 